\title{
Risk factors for linezolid-associated thrombocytopenia in adult patients
}

\author{
B. Natsumoto $\cdot$ K. Yokota $\cdot$ F. Omata $\cdot$ \\ K. Furukawa
}

Received: 27 May 2014/ Accepted: 28 July 2014/Published online: 14 August 2014

(C) The Author(s) 2014. This article is published with open access at Springerlink.com

\begin{abstract}
Objectives Thrombocytopenia (TP) is a common adverse effect of linezolid (LZD). However, risk factors for LZDassociated TP have been reported in Western patients with relatively heavy body weight. The aim of this study was to determine the risk factors for LZD-associated TP in Asian population.

Materials and methods A retrospective cohort study was conducted among 101 consecutive patients who received LZD therapy $(1,200 \mathrm{mg} /$ day $)$ between July 2003 and December 2013 at a tertiary referral hospital in Tokyo, Japan. The patients with obvious other causes for TP were excluded. The information of target infectious disease, patients' age, gender, body weight, body mass index, baseline serum creatinine ( $\mathrm{SCr}$ ), baseline platelet count, and treatment duration was collected retrospectively. TP was defined as $\geq 50 \%$ decrease in platelet count from baseline. Bi- and multi-variate analyses were performed.

Results A total of 101 patients were included (mean age [SD] 64 [18]; male gender [\%], 57 [56]). Median duration
\end{abstract}

B. Natsumoto $(\bowtie) \cdot$ F. Omata

Department of Internal medicine, St. Luke's International

Hospital, 9-1 Akashi-Cho, Chuo-ku, Tokyo 104-8560, Japan

e-mail: natsumotobunki@gmail.com

K. Yokota

Department of Infectious Diseases, University of Kagawa,

1750-1 Ikedo, Mikichou, Kida-gunn, Kagawa 761-0793, Japan

F. Omata

Center for Clinical Epidemiology, St. Luke's Life Science Institute, 10-1 Akashi-Cho, Chuo-ku, Tokyo 104-0044, Japan

K. Furukawa

Department of Infectious Diseases, St. Luke's Life Science Institute, 9-1 Akashi-Cho, Chuo-ku, Tokyo 104-8560, Japan [range] of LZD therapy was 14 days [1-67]. LZD-associated TP was identified in 42 patients $(42 \%)$. For TP, adjusted odds ratio (OR) [95\% CI] of daily per $\mathrm{kg}$ dose (DPKD) and $\mathrm{SCr}$ was $1.14 \quad[1.05-1.26]$ and 1.51 [1.01-2.50], respectively.

Conclusions Higher DPKD and elevated SCr are significantly associated with LZD-associated TP. These findings suggest that daily dose of LZD should be adjusted using body weight, as typically done in pediatrics, in adults as well. Renal function also should be considered for dose adjustment.

Keywords Linezolid $\cdot$ Thrombocytopenia $\cdot$ Dose $\cdot$ Adult

\section{Introduction}

Linezolid (LZD) is an antimicrobial agent with a broad spectrum of activity against virtually all clinically important Gram-positive bacteria, including methicillin-resistant Staphylococcus aureus (MRSA) and vancomycin-resistant enterococci (VRE). An oxazolidinone, its mechanism of antimicrobial action is primarily bacteriostatic, inhibiting bacterial toxin production. Both the intravenous and oral formulations of LZD have nearly $100 \%$ bioavailability due to its high water solubility and robust tissue penetration $[1,2]$. LZD does not typically require dose adjustment by body weight (BW) in adults, though dose is determined by weight in pediatric patients [3, 4]. Thrombocytopenia (TP) is a common adverse effect in adult patients and the prevalence has been reported about $15-50 \%$ with different definitions [5-9]. Prolonged treatment duration [9, 10], renal insufficiencies [1, 2, 9, 11-13], chronic liver disease [11], malignancy [14], previous vancomycin use [15], baseline platelet count [16], and lower BW [7, 8, 17] have 
been reported as possible risk factors for LZD-associated TP. However, most of previous studies have been conducted in Western patients with relatively heavy BW. The aim of this study was to identify the independent risk factors for LZD-associated TP in Asian population.

\section{Materials and methods}

A retrospective cohort study was conducted among 101 consecutive patients who received LZD therapy $(1,200 \mathrm{mg} /$ day) for the first time between July 2003 and December 2013 at a tertiary referral hospital in Tokyo, Japan. Within the study period, 230 adults (age $\geq 20$ ) have received LZD therapy. Those who had previously received LZD therapy $(n=85)$, with an acute DIC score $\geq 4$ points $(n=24)$ [18], a hematological disorder $(n=15)$, or a definite diagnosis of prior drug-associated TP $(n=5)$ were excluded.

All patients received a total daily dose of $1,200 \mathrm{mg}$ (600 mg, q12hr) regardless of BW. The information of target infectious disease, patients' age, gender, BW, body mass index (BMI), baseline serum creatinine ( $\mathrm{SCr}$ ), baseline platelet count, and treatment duration was collected retrospectively. TP was defined as $\geq 50 \%$ platelet count decrease from baseline [19]. Baseline platelet count was defined as platelet count at initiation of LZD therapy. If there was no platelet data on the first day of LZD therapy, the closest previous platelet data prior to LZD therapy was used as baseline platelet count. Laboratory data were obtained between baseline and 14 days after discontinuation of LZD. Platelets were measured 2-3 times per week. Bi- and multi-variate analyses were performed.

\section{Statistical analysis}

Fisher's exact test was used for comparison of proportions, while Student's $t$ test was used for continuous variables. Bivariate and multivariate logistic regression analyses were subsequently conducted. Variables with $P$ value less than 0.2 in bivariate analyses were principally added in multivariate analysis. Clinically relevant variables which have been previously reported to be associated with TP were also included in multivariate analysis.

All analyses including confidence intervals were twosided, and $P<0.05$ was considered statistically significant. All statistical analyses were performed using JMP ${ }^{\circledR}$ version 10 statistical software (SAS ${ }^{\circledR}$ Institute, Cary, NC).

\section{Results}

A total of 101 patients were included in our analysis. Baseline characteristics are listed in Table 1. The patients' mean age was 64 years, $56 \%$ of them were male. Mean body weight was $57.3 \mathrm{~kg}$. Patient with BMI less than 20 was $33 \%$. Mean (SD) daily per $\mathrm{kg}$ dose (DPKD) $(\mathrm{mg} / \mathrm{kg} /$ day) of LZD was 21.39 (5.51). Its range ( $\mathrm{mg} / \mathrm{kg} /$ day) was [7.95-35.29]. Median duration [range] of LZD therapy was 14 days [1-67].

LZD was mainly administrated for surgical infection, cellulitis, urinary tract infection, artificial device infection and osteomyelitis (Table 1). The main indication of LZD was definite or suspected MRSA infection. For these patients, LZD was chosen for following reasons: (1) side effects of other anti-MRSA antibiotics (49\%); (2) antibiotics failure (31\%); and (3) outpatient therapy (29\%). In $24 \%$ of the total cases (MRSA $16.8 \%$, possible MRSA

Table 1 Patients' characteristics

\begin{tabular}{|c|c|}
\hline Characteristics and underlying medical conditions & Value \\
\hline Number of patients & 101 \\
\hline Age (years) $)^{\mathrm{a}}$, mean $(\mathrm{SD})$ & $64(18)$ \\
\hline Male, $n(\%)$ & $57(56)$ \\
\hline $\mathrm{BW}(\mathrm{kg})^{\mathrm{a}}$, mean $(\mathrm{SD})$ & $57.3(17.3)$ \\
\hline BMI $\left(\mathrm{kg} / \mathrm{m}^{2}\right)^{\mathrm{a}}$, mean $(\mathrm{SD})$ & $23.02(6.6)$ \\
\hline BMI less than $20, n(\%)$ & $33(33)$ \\
\hline Treatment duration (days), median (range) & $14(1-67)$ \\
\hline DPKD $(1,200 / \mathrm{BW}(\mathrm{mg} / \mathrm{kg}))$, mean (SD) & $21.39(5.51)$ \\
\hline Serum creatinine $(\mathrm{mg} / \mathrm{dL})^{\mathrm{a}}$, median (range) & $0.87(0.24-7.47)$ \\
\hline eGFR $\left(\mathrm{mL} / \mathrm{min} / 1.73 \mathrm{~m}^{2}\right)^{\mathrm{a}}$, median (range) & $61.58(6.64-325.43)$ \\
\hline $\mathrm{CCr}(\mathrm{mL} / \mathrm{min})^{\mathrm{a}}$, median (range) & $61.29(9.76-557.07)$ \\
\hline Baseline Plt $\left(\times 10^{3} / \mu \mathrm{L}\right)^{\mathrm{a}}$, mean $(\mathrm{SD})$ & $266(133)$ \\
\hline \multicolumn{2}{|l|}{ Diagnosis } \\
\hline Surgical site infection, $n(\%)$ & $21(20.8)$ \\
\hline Cellulitis, $n(\%)$ & $15(14.9)$ \\
\hline Urinary tract infection, $n(\%)$ & $12(11.9)$ \\
\hline Artificial device infection ${ }^{\mathrm{b}}, n(\%)$ & $10(9.9)$ \\
\hline Osteomyelitis, $n(\%)$ & $7(6.9)$ \\
\hline Pneumonia, $n(\%)$ & $5(5.0)$ \\
\hline Pyothorax, $n(\%)$ & $4(4.0)$ \\
\hline Infective endocarditis, $n(\%)$ & $3(3.0)$ \\
\hline Epidural abscess, $n(\%)$ & $2(2.0)$ \\
\hline Pyogenic arthritis, $n(\%)$ & $2(2.0)$ \\
\hline Toxic shock syndrome, $n(\%)$ & $2(2.0)$ \\
\hline Perforation of gastrointestinal tract, $n(\%)$ & $2(2.0)$ \\
\hline Others, $n(\%)$ & $14(13.9)$ \\
\hline \multicolumn{2}{|l|}{ Baseline disease } \\
\hline Diabetes mellitus, $n(\%)$ & $34(33.7)$ \\
\hline Hypertension, $n(\%)$ & $58(57.4)$ \\
\hline Hyperlipidemia, $n(\%)$ & $38(37.6)$ \\
\hline
\end{tabular}

$B W$ body weight, $B M I$ body mass index, $D P K D$ daily per kg dose, $e G F R$ estimated glomerular filtration rate, $C C r$ creatinine clearance

a Before linezolid administration

${ }^{b}$ Eight cases of intravascular device, one case of urine stent, one case of artificial breast (post expander-implant breast reconstruction) 
Table 2 Bivariate analyses

\begin{tabular}{|c|c|c|c|}
\hline & $\begin{array}{l}\text { Thrombocytopenic } \\
\text { patients }(n=42)\end{array}$ & $\begin{array}{l}\text { Non- } \\
\text { thrombocytopenic } \\
\text { patients }(n=59)\end{array}$ & $P$ value \\
\hline $\begin{array}{l}\text { Age, mean } \\
\quad(\mathrm{SD})\end{array}$ & 67.83 (15.59) & $61.76(19.05)$ & $0.041 * *$ \\
\hline Male, $n(\%)$ & $22(38.60)$ & 35 (61.4) & $0.49 * *$ \\
\hline $\begin{array}{l}\text { DPKD } \\
\qquad(1,200 / \mathrm{BW}) \\
(\mathrm{mg} / \mathrm{kg} / \mathrm{day}) \\
\text { mean (SD) }\end{array}$ & $23.47(5.10)$ & $19.91(5.35)$ & $0.0011 * *$ \\
\hline $\begin{array}{l}\mathrm{BW}(\mathrm{kg}) \\
\text { mean }(\mathrm{SD})\end{array}$ & $53.64(12.12)$ & 64.75 (18.94) & $0.0012 * *$ \\
\hline $\begin{array}{l}\mathrm{SCr}(\mathrm{mg} / \mathrm{dL}), \\
\text { median (range) }\end{array}$ & $0.96(0.24-7.47)$ & $0.85(0.24-3.93)$ & $0.17^{*}$ \\
\hline $\begin{array}{l}{ }^{\mathrm{a}} \mathrm{CCr}(\mathrm{mL} / \\
\text { min), median } \\
\text { (range) }\end{array}$ & $\begin{array}{l}52.67 \\
\quad(9.76-153.73)\end{array}$ & $78.36(13.63-557.07)$ & $0.0299 *$ \\
\hline $\begin{array}{l}\text { Baseline } \\
\text { platelet } \\
\left(10^{3} / \mathrm{mm}^{3}\right) \text {, } \\
\text { mean }(\mathrm{SD})\end{array}$ & $289.98(20.37)$ & $249.63(17.19)$ & $0.13 * *$ \\
\hline $\begin{array}{l}\text { Treatment } \\
\text { duration } \\
\text { (days), } \\
\text { median (range) }\end{array}$ & $14(3-67)$ & $14(1-63)$ & $0.36^{*}$ \\
\hline
\end{tabular}

* Kruskal-Wallis test

** Student's $t$ test

${ }^{\text {a }} \mathrm{CCr}(\mathrm{mL} / \mathrm{min})=(140-$ age $) \times$ weight/72 SCr, female times 0.85 . Formula of Cockcroft

$S D$ standard deviation, $D P K D$ daily per $\mathrm{kg}$ dose, $B W$ body weight, $\mathrm{SCr}$ serum creatinine, $\mathrm{CCr}$ creatinine clearance

Table 3 Bi-and multi-variate logistic regression

\begin{tabular}{|c|c|c|c|c|}
\hline & Crude OR & $P$ value & $\begin{array}{l}\text { Adjusted OR } \\
(95 \% \text { CI })\end{array}$ & $P$ value \\
\hline Age & $\begin{array}{l}1.02 \\
(0.99-1.05)\end{array}$ & 0.09 & $\begin{array}{l}1.01 \\
\quad(0.98-1.04)\end{array}$ & 0.44 \\
\hline $\mathrm{SCr}(\mathrm{mg} / \mathrm{dL})$ & $\begin{array}{l}1.31 \\
\quad(0.90-2.07)\end{array}$ & 0.16 & $\begin{array}{l}1.51 \\
\quad(1.01-2.50)\end{array}$ & 0.0457 \\
\hline $\begin{array}{l}\text { DPKD }(\mathrm{mg} / \mathrm{kg} / \\
\text { day) }\end{array}$ & $\begin{array}{l}1.14 \\
\quad(1.05-1.24)\end{array}$ & 0.001 & $\begin{array}{l}1.14 \\
\quad(1.05-1.26)\end{array}$ & 0.0026 \\
\hline $\begin{array}{c}\text { Treatment } \\
\text { duration }\end{array}$ & $\begin{array}{l}1.01 \\
\quad(0.98-1.03)\end{array}$ & 0.71 & $\begin{array}{l}1.01 \\
\quad(0.98-1.05)\end{array}$ & 0.52 \\
\hline $\begin{array}{l}\text { Baseline platelet } \\
\quad<200 \times 10^{3} / \\
\mu \mathrm{L}\end{array}$ & $\begin{array}{l}0.81 \\
\quad(0.34-1.87)\end{array}$ & 0.62 & $\begin{array}{l}1.00 \\
\quad(0.99-1.01)\end{array}$ & 0.24 \\
\hline
\end{tabular}

OR odds ratio, $C I$ confidence interval, $S C r$ serum creatinine, $D P K D$ daily per $\mathrm{kg}$ dose

$6.9 \%$ ), LZD was administered due to the failure of other antimicrobial therapy. Patients with VRE infection were rare $(3.9 \%)$.

LZD-associated TP was found in 42 of 101 patients (42\%). The mean age, and DPKD were significantly

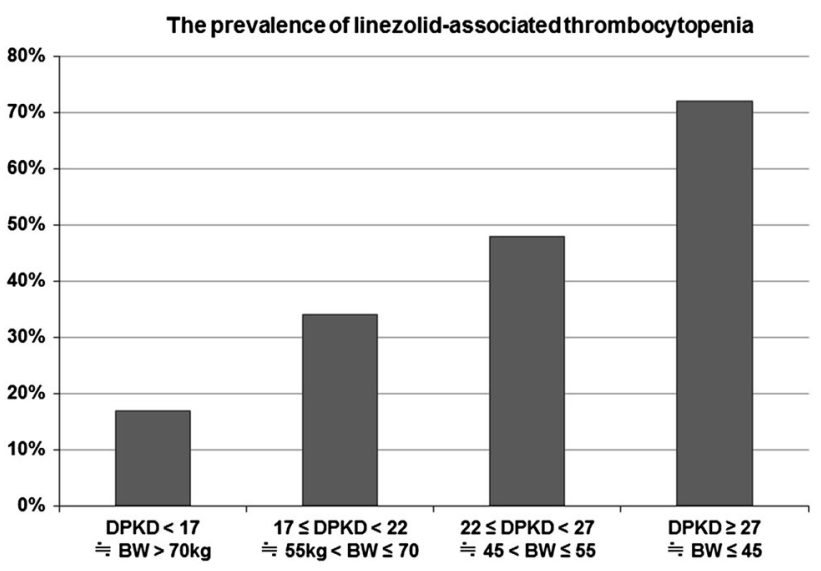

Fig. 1 The prevalence of linezolid-associated thrombocytopenia stratified by daily per $\mathrm{kg}$ dose (DPKD) $(\mathrm{mg} / \mathrm{kg} / \mathrm{day})$. The prevalence of thrombocytopenia is linearly associated with DPKD of linezolid. In $22 \leq \mathrm{DPKD}<27$, the prevalence of TP was $48 \%$. Its prevalence increased to $72 \%$ in DPKD $\geq 27$

higher in thrombocytopenic patients than in non-thrombocytopenic patients. The median creatinine clearance $(\mathrm{CCr})$ was significantly lower in thrombocytopenic patients (Table 2). Platelet decreases of $\geq 50 \%$ and final platelet counts of $<150 \times 10^{3} / \mu \mathrm{L}$ were identified in $31 \%(31 / 101)$ of patients. TP with a final count of $<100 \times 10^{3} / \mu \mathrm{L}$ was seen in $26 \%(26 / 101)$ of patients. Age, DPKD, BW and $\mathrm{CCr}$ were significantly associated with LZD-induced TP in bivariate analyses. For TP, adjusted odds ratio (OR) [95\% $\mathrm{CI}]$ of DPKD and SCr was 1.14 [1.05-1.26] and 1.51 [1.01-2.50], respectively (Table 3).

When patients were categorized into four groups using three cut-off values $(45,55,75 \mathrm{~kg})$ of $\mathrm{BW}$, the prevalence of TP in each group was $72 \%$ (13/18), $48 \%$ (12/25), $34 \%$ (13/ $38)$, and $17 \%(4 / 23)$ in the patients with $\mathrm{DPKD} \geq 27$ $(\mathrm{BW} \leq 45 \mathrm{~kg}), 22 \leq \mathrm{DPKD}<27(45 \mathrm{~kg}<\mathrm{BW} \leq 55 \mathrm{~kg})$, $17 \leq \mathrm{DPKD}<22 \quad(55 \mathrm{~kg}<\mathrm{BW} \leq 70 \mathrm{~kg}), \quad$ DPKD $<17$ (BW $>70 \mathrm{~kg}$ ), respectively (Fig. 1).

\section{Discussion}

Our study suggests that LZD-associated TP is associated with high DPKD and renal insufficiency.

The mechanism of LZD-associated TP is thought to be due to reversible myelosuppression [20]. Nonetheless, several case reports suggested that patients with LZDassociated TP retain adequate numbers of megakaryocytes in their bone marrow [21, 22]. Immune-mediated platelet destruction has been suggested based on a decreased rate of TP following immunoglobulin therapy [21]. Given multiple plausible mechanisms, the pathophysiology of LZDassociated TP remains controversial. 
Niwa et al. [17], though using a different definition of TP at $\geq 25 \%$ platelet decrease and final platelet count of $<100 \times 10^{3} / \mu \mathrm{L}$, reported that DPKD $\geq 22 \mathrm{mg} / \mathrm{kg}$ and a baseline platelet count $<200 \times 10^{3} / \mu \mathrm{L}$ were significant risk factors for LZD-associated TP. Their study introduced the possibility of dose modification with linezolid [23]. In our study, we defined TP as a platelet decrease of $\geq 50 \%$ as this level, while platelet count still in the normal range, may herald severe clinical problems, and requires active followup. Vanderschueren et al. [19] reported that drop in platelet count to $<50 \%$ of admission was associated with higher death rates in the ICU patients. Under this definition, LZDassociated TP was found in 42 of 101 patients (42\%) (Table 2). Considering the DPKD of $22 \mathrm{mg} / \mathrm{kg}$ that Niwa reported, when the patients were divided into four groups $[$ DPKD $\geq 27(\fallingdotseq \mathrm{BW} \leq 45 \mathrm{~kg}), 22 \leq \mathrm{DPKD}<27(\fallingdotseq 45 \mathrm{~kg}$ $<\mathrm{BW} \leq 55 \mathrm{~kg}), \quad 17 \leq \mathrm{DPKD}<22 \quad(\fallingdotseq 55 \mathrm{~kg}<\mathrm{BW} \leq$ $70 \mathrm{~kg}), \mathrm{DPKD}<17(\fallingdotseq \mathrm{BW}>70 \mathrm{~kg})$ ], the prevalence of TP increased to $72 \%$ in the group of DPKD $\geq 27(\fallingdotseq \mathrm{BW}$ $\leq 45 \mathrm{~kg}$ ) (Fig. 1) is an impressive result.

A recent randomized controlled study [5] reported that the incidence of LZD-associated TP (platelet count, $<150 \times 10^{3} / \mu \mathrm{L}$ if normal at baseline or $50 \%$ decrease if low at baseline) was $16.3 \%$, the mean BW (SD) of subjects being $78.1 \mathrm{~kg}$ (23.3). This prevalence rate is similar to the prevalence of TP in the DPKD $<17$ category in our study.

According to LZD phase 3 trials in Japan, adverse events developed in $64.3 \%(9 / 14)$ in those subjects with BW $<40 \mathrm{~kg}$, and $53 \%(44 / 83)$ in those with BW $\geq 40 \mathrm{~kg}$ [24]. These findings were similar to our results, in which the prevalence of TP was $70 \%$ in patient $\leq 45 \mathrm{~kg}$.

In pediatric patients, especially those with lower BW, the daily dose of LZD requires adjustment by BW. We think that it is similarly reasonable to suggest weight-based dosing for LZD even in relatively lower weight adults.

Elevated $\mathrm{SCr}$ was also independently associated with LZD-associated TP. A previous phase 3 trial [24] showed that the pharmacokinetics of LZD is not influenced by age, hepatic function, or renal function $(\mathrm{CCr}>30)$. Moreover, in serial oral administration tests for patients with endstage renal disease, plasma LZD concentrations were not influenced by renal function [24]. LZD is metabolized by non-enzymatic chemical oxidation and $30-40 \%$ is excreted unchanged in the urine [25-30]. It is thought that LZD is not metabolized by cytochrome P450, as it shows none of the induction or inhibitory effects associated with various human cytochrome P450 enzyme activities. However, after coming to market, the association between LZDassociated adverse events (including TP) and renal insufficiency [1, 2, 12], chronic liver disease [12], prolonged administration [11], malignancy [15] and previous vancomycin use [16] have been reported. In particular, renal insufficiency has been reported frequently as a risk factor of LZD-associated TP in recent studies [1, 2, 31, 32]. Our results corroborate these findings. Prolonged treatment duration (TD) of LZD was reported as the main risk factor of LZD-associated TP [16, 33]. However, our study showed no association between TD and TP.

Area under the blood concentration-time curve (AUC) value of LZD has been reported to be higher in subject older than 80 years and BW less than 40 [24]. The mean AUC value (SD) of these subjects was 811.3 (280.7) $\mu \mathrm{g} \mathrm{h} / \mathrm{mL}$. This value is 3.7 times of the subjects with age $<80$ and BW $\geq 40$ [217.6 (129.9) $\mu \mathrm{g} \mathrm{h} / \mathrm{mL}$ ] [24]. On the safety of high-exposure examination, adverse event prevalence was found in 7 of 11 subject $(63.6 \%)$ in the high-exposure subjects (AUC $\geq 800 \mu \mathrm{g} \mathrm{h} / \mathrm{mL}$ ), 41 of $80(51.3 \%$ ) in the non-high-exposure subjects (AUC $<800 \mu \mathrm{g} \mathrm{h} / \mathrm{mL}$ ). Nukui et al. [32] reported that high plasma LZD trough concentration is a risk factor for TP. Dong et al. [7] reported the minimum trough level $\left(C_{\min }\right)$ of linezolid was significantly higher in patients with TP than in those without TP $(8.81 \mathrm{mg} / \mathrm{L} \quad$ [1.98-37.54] vs. $2.88 \mathrm{mg} / \mathrm{L} \quad$ [0.35-8.78], $P<0.0001)$. Matsumoto et al. [34] reported that the trough concentration of LZD [mg/L] was $14.4-35.6$ versus (vs.) 6.9-7.2 and the area under the plasma linezolid concentration-time curve for $24 \mathrm{~h}($ AUC24 h) $[\mathrm{mg} \mathrm{h} / \mathrm{L}]$ was $513.1-994.6$ vs. $294.3-323.6$ in the thrombocytopenic vs. non-thrombocytopenic patients. In addition, several recent Japanese studies have discussed the relationship between LZD blood concentration and TP [35-37]. As mentioned above, the fact that AUC value of LZD is relatively high in low BW subjects has been previously demonstrated in the phase 3 clinical trials in Japan [24]. Our results strongly suggest that high DPKD and elevated $\mathrm{SCr}$ are independently associated with LZD-associated TP. Therefore, we assume that higher DPKD and renal dysfunction are related to TP via higher serum LZD concentrations.

This is the first study suggesting a DPKD-dependent linear association between LZD and TP by categorizing DPKD into four groups. As this is a single center study among Japanese, our findings warrant external validation.

In conclusion, both higher DPKD and elevated $\mathrm{SCr}$ are significant risk factors for LZD-associated TP. As is done in pediatric patients, the daily dose of LZD should be adjusted by BW in adults as well. Renal function also should be considered for dose adjustment.

Acknowledgments We wish to thank Dr. Gautam Anil Deshpande for refining our manuscript.

Funding This study did not receive any funding.

Conflict of interest The authors declare that they have no conflict of interest. 
Ethical approval Study design has been approved by the ethics committee of the St. Lukes International Hospital, Japan.

Open Access This article is distributed under the terms of the Creative Commons Attribution License which permits any use, distribution, and reproduction in any medium, provided the original author(s) and the source are credited.

\section{References}

1. Lin $\mathrm{YH}, \mathrm{Wu} \mathrm{VC}$, Tsai IJ, et al. High frequency of linezolidassociated thrombocytopenia among patients with renal insufficiency. Int J Antimicrob Agents. 2006;28:345-51.

2. Wu VC, Wang YT, Wang CY, et al. High frequency of linezolidassociated thrombocytopenia and anemia among patients with end-stage renal disease. Clin Infect Dis. 2006;42:66-72.

3. Jungbluth GL, Welshman IR, Hopkins NK. Linezolid pharmacokinetics in pediatric patients: an overview. Pediatr Infect Dis. 2003;22:S153-7.

4. Chiappini E, Conti C, Galli L, et al. Clinical efficacy and tolerability of linezolid in pediatric patients: a systematic review. Clin Ther. 2010;32:66-88.

5. Wunderink RG, Niederman MS, Kollef MH, et al. Linezolid in methicillin-resistant Staphylococcus aureus nosocomial pneumonia: a randomized. Controlled Study. Clin Infect Dis. 2012;54:621-9.

6. Bi LQ, Zhou J, Huang M, et al. Efficacy of linezolid on grampositive bacterial infection in elderly patients and the risk factors associated with thrombocytopenia. Pak J Med Sci. 2013; 29:837-42.

7. Dong HY, Xie J, Chen LH, et al. Therapeutic drug monitoring and receiver operating characteristic curve prediction may reduce the development of linezolid-associated thrombocytopenia in critically ill patients. Eur J Clin Microbiol Infect Dis. 2014;33: 1029-35.

8. Chen C, Guo DH, Cao X, et al. Risk factors for thrombocytopenia in adult Chinese patients receiving linezolid therapy. Curr Ther Res Clin Exp. 2012;73:195-206.

9. Hirano R1, Sakamoto Y, Tachibana N, et al. Retrospective analysis of the risk factors for linezolid-induced thrombocytopenia in adult Japanese patients. Int J Clin Pharm. 2014;36:795-9.

10. Attassi K, Hershberger E, Alam R, et al. Thrombocytopenia associated with linezolid therapy. Clin Infect Dis. 2002;34:695-8.

11. Sasaki T, Takane H, Ogawa K, et al. Population pharmacokinetic and pharmacodynamic analysis of linezolid and a hematologic side effect, thrombocytopenia, in Japanese patients. Antimicrob Agents Chemother. 2011;55:1867-73.

12. Cossu AP, Musu M, Mura P, et al. Linezolid-induced thrombocytopenia in impaired renal function: is it time for a dose adjustment? a case report and review of literature. Eur J Clin Pharmacol. 2014;70:23-8.

13. Soriano A, Ortega M, García S, et al. Comparative study of the effects of pyridoxine, rifampin, and renal function on hematological adverse events induced by linezolid. Antimicrob Agents Chemother. 2007;51:2559-63.

14. Smith PF, Birmingham MC, Noskin GA, et al. Safety, efficacy and pharmacokinetics of linezolid for treatment of resistant Gram-positive infections in cancer patients with neutropenia. Ann Oncol. 2003;14:795-801.

15. Rao N, Ziran BH, Wagener MM, et al. Similar hematologic effects of long-term linezolid and vancomycin therapy in a prospective observational study of patients with orthopedic infections. Clin Infect Dis. 2004;38:1058-64.
16. Grau S, Morales-Molina JA, Mateu-de Antonio J, et al. Linezolid: low pre-treatment platelet values could increase the risk of thrombocytopenia. J Antimicrob Chemother. 2005;56:440-1.

17. Niwa T, Suzuki A, Sakakibara S, et al. Retrospective cohort chart review study of factors associated with the development of thrombocytopenia in adult Japanese patients who received intravenous linezolid therapy. Clin Ther. 2009;31:2126-33.

18. Gando S, Iba T, Eguchi Y, et al. A multicenter, prospective validation of disseminated intravascular coagulation diagnostic criteria for critically ill patients: comparing current criteria. Crit Care Med. 2006;34:625-31.

19. Vanderschueren S, De Weerdt A, Malbrain M, et al. Thrombocytopenia and prognosis in intensive care. Crit Care Med. 2000;28:1871-6.

20. Senneville E, Legout L, Valette M, et al. Risk factors for anaemia in patients on prolonged linezolid therapy for chronic osteomyelitis: a case-control study. J Antimicrob Chemother. 2004;54: 798-802.

21. Bernstein WB, Trotta RF, Rector JT, et al. Mechanisms for linezolid-induced anemia and thrombocytopenia. Ann Pharmacother. 2003;37:517-20.

22. Ebeling F, Helminen P, Anttila VJ. Appearance of ring sideroblasts in bone marrow during linezolid therapy. Scand $\mathbf{J}$ Infect Dis. 2009;41:480-2.

23. Niwa T, Watanabe T, Suzuki A, et al. Reduction of linezolidassociated thrombocytopenia by the dose adjustment based on the risk factors such as basal platelet count and body weight. Diagn Microbiol Infect Dis. 2014;79:93-7.

24. Linezolid application document for the manufacture and sales approval in Japan. PMDA website http://www.info.pmda.go.jp/ downfiles/ph/PDF/671450_6249401A1025_4_11.pdf

25. Slatter JG, Stalker DJ, Feenstra KL, et al. Pharmacokinetics, metabolism, and excretion of linezolid following an oral dose of [14C]linezolid to healthy human subjects. Drug Metab Dispos. 2001;29:1136-45.

26. Abe S, Chiba K, Cirincione B, et al. Population pharmacokinetic analysis of linezolid in patients with infectious disease: application to lower body weight and elderly patients. J Clin Pharmacol. 2009;49:1071-8.

27. McGee B, Dietze R, Hadad DJ, et al. Population pharmacokinetics of linezolid in adults with pulmonary tuberculosis. Antimicrob Agents Chemother. 2009;53:3981-4.

28. Meagher AK, Forrest A, Rayner CR, et al. Population pharmacokinetics of linezolid in patients treated in a compassionate-use program. Antimicrob Agents Chemother. 2003;47:548-53.

29. Plock N, Buerger C, Joukhadar C, et al. Does linezolid inhibit its own metabolism? population pharmacokinetics as a tool to explain the observed nonlinearity in both healthy volunteers and septic patients. Drug Metab Dispos. 2007;35:1816-23.

30. Whitehouse T, Cepeda JA, Shulman R, et al. Pharmacokinetic studies of linezolid and teicoplanin in the critically ill. J Antimicrob Chemother. 2005;55:333-40.

31. Matsumoto K, Takeda Y, Takeshita A, et al. Renal function as a predictor of linezolid-induced thrombocytopenia. Int J Antimicrob Agents. 2009;33:98-9.

32. Nukui Y, Hatakeyama S, Okamoto K, et al. High plasma linezolid concentration and impaired renal function affect development of linezolid-induced thrombocytopenia. J Antimicrobial Chemotherapy. 2013;68:2128-33.

33. Gerson SL, Kaplan SL, Bruss JB, et al. Hematologic effects of linezolid: summary of clinical experience. Antimicrob Agents Chemother. 2002;46:2723-6.

34. Matsumoto K, Takeshita A, Ikawa K, et al. Higher linezolid exposure and higher frequency of thrombocytopenia in patients with renal dysfunction. Int $\mathbf{J}$ Antimicrob Agents. 2010;36: 179-81. 
35. Tsuji Y, Hiraki Y, Matsumoto K, et al. Thrombocytopenia and anemia caused by a persistent high linezolid concentration in patients with renal dysfunction. J Infect Chemother. 2011; 17:70-5.

36. Hiraki Y, Tsuji Y, Matsumoto K, et al. Influence of linezolid clearance on the induction of thrombocytopenia and reduction of hemoglobin. Am J Med Sci. 2011;342:456-60.
37. Hiraki Y, Tsuji Y, Hiraike M, et al. Correlation between serum linezolid concentration and the development of thrombocytopenia. Scand J Infect Dis. 2012;44:60-4. 